Short Communication

Animal Genetics

\title{
Comparison of the heterochromatin and telomeric sequences distribuition in chromosomes of 11 species of Amazonian marsupials (Didelphimorphia; Didelphidae)
}

\author{
Carlos Eduardo Faresin e Silva ${ }^{1}$, Érica Martinha Silva de Souza ${ }^{1}$ (이 , Eduardo Schmidt Eler ${ }^{1,3}$ (ㅇ) , Maria \\ Nazareth Ferreira da Silva ${ }^{2}$ and Eliana Feldberg ${ }^{1 *}$ (1) \\ ${ }^{1}$ Instituto Nacional de Pesquisas da Amazônia, Laboratório de Genética Animal, Manaus, AM, Brazil. \\ ${ }^{2}$ Instituto Nacional de Pesquisas da Amazônia, Coleção de Mamíferos, Manaus, AM, Brazil. \\ ${ }^{3}$ Universidade Anhembi Morumbi, Escola de Ciências da Saúde, São José dos Campos, SP, Brazil.
}

\begin{abstract}
In recent decades the diploid numbers recorded in the New World marsupials have been widely discussed in the context of the processes of karyotype evolution in these mammals. While Interstitial Telomeric Sequences (ITS) have long been interpreted as remnants of chromosomal fusion, the biological role of these features, together with their intraspecific variation, has raised a number of questions. In the present study, we analyzed the karyotype of 11 species of Amazonian didelphids, comparing the distribution of the heterochromatin with that of the telomeric signals, and found that, in six species, the ITS coincided with the blocks of heterochromatin. While ITS were found in the $X$ chromosomes of all Marmosa murina individuals, they were variable in all the other species, representing a specific character of each lineage. Our results support the conclusion that ITS may not always be a consequence of chromosomal rearrangements, and that the mechanisms that produce them are still unclear.
\end{abstract}

Keywords: C-banding, ITS, repetitive sequences, FISH.

Received: October 21, 2019; Accepted: February 18, 2020.

The most common diploid numbers among marsupials are $2 n=14$ and $2 n=22$, in both New World and Australian species (Sharman, 1961, 1982; Biggers et al., 1965; Hayman and Martin, 1974; Rofe and Hayman, 1985; Hayman, 1990). There is also a high degree of homeology among these species in the chromosome arms (De Leo et al., 1999; Rens et al., 1999). Based on these chromosomal homeologies, the marsupials are highly conserved, with the principal chromosomal rearrangements occurring through fusions or fissions (Reig et al., 1977; O'Neill et al., 1999; Rens et al., 2003).

Comparative phylogenetic analyses of karyotypes have shown that the most common marsupial karyotypes have arisen more than once in different lineages, and according to Westerman et al. (2010), are invariably derived from the $2 n=14$ through fissions. In this context, the mapping of telomere sequences has provided an important complementary perspective for the understanding of the karyotypic evolution of these organisms (Svartman and Vianna-Morgante, 1998).

Send correspondence to Eliana Feldberg. Instituto Nacional de Pesquisas da Amazônia, Laboratório de Genética Animal, Campus 2, Avenida André Araújo 2936, 69.067-375, Manaus, AM, Brazil. E-mail: feldberg@inpa.gov.br.
Telomeric sequences are highly conserved and they protect the cohesive extremities of the linear eukaryote chromosome, preventing their interaction with other chromatids and the action of DNases (McClintock, 1941; Meyne et al., 1989; Blackburn, 1991). However, these sequences have been found not only in telomeric regions, but also in interstitial (ITS) or centromeric regions, where they are interpreted as being the result of damage to the DNA, or the action of dispersed repetitions and chromosomal reorganization (Azzalin et al., 2001; Ruiz-Herrera et al., 2008; Sánchez et al., 2010). Whatever their origin, the ITSs may be fixed in the genome, operating as markers for the analysis of evolutionary processes (Nergadze et al., 2004).

In the Didelphidae, these sequences have been detected in centromeric regions, in species with both $2 n=14$ and $2 n=18$ chromosomes, which indicates that they are remnants of fusions from a $2 n=22$ karyotype (Svartman and Vianna-Morgante, 1998; Carvalho and Mattevi, 2000). However, Pagnozzi et al. $(2000,2002)$ analyzed these markers in didelphid species, and found that the ITSs overlap with the heterochromatin and varied in number intraspecifically, indicating that they were not necessarily the result of recent fusions. Metcalfe et al. (2004) also concluded that not all the ITSs found in Australian marsupials of the family Macropodidae are evidence of fusions, except when 
they are the principal components of the heterochromatin. Subsequently, Svartman (2009) concluded that condensation of the chromosomes may make the mapping of telomeric sequences relatively imprecise, given that they are visualized in the region of the pericentromeric heterochromatin, when in fact these sequences are not located within the heterochromatin.

Comparative cytogenetic analyses are available for a large number of Australian marsupials, supporting inferences on their evolutionary patterns and the origin of their karyotypes. However, much fewer data are available for the New World, particularly for Amazonian species (Nagamachi et al., 2015). The present study compared the position of the ITS and heterochromatin blocks in 11 didelphid species, all sampled in the Brazilian Amazon region, with the aim of shading light on the evolutionary patterns of this group.

We analyzed 11 Amazonian marsupial species, representing eight of the 12 genera, collected at 12 distinct localities (Figure 1, Table 1). We analyzed the same group of individuals as Silva et al. (2017). The individuals were identified by one of us (MNFS), using morphological and chromosomal characters. All voucher specimens were deposited in the Mammal Collection of the National Institute of Amazonian Research (INPA) in Manaus, Brazil (Supplementary Material).

The mitotic chromosomes were obtained in the field, from bone marrow, using the in vivo method described by Ford and Harmerton (1956). The comparative C-banding patterns were those described in Silva et al. (2017) that based their analyses on the technique described by Sumner (1972). Telomeric sequences were mapped using Fluorescent in situ Hybridization (FISH), as in Pinkel et al. (1986, with adaptations), with a stringency of $77 \%$. The probes were obtained by PCR using standard primers for mammals, these being (TTAGGG) $)_{5}$ and(CCCTAA $)_{5}$ (Ijdo et al., 1991). The karyotypes were arranged based on the scheme of Patton (1967).

The C-banding patterns used for comparisons were those in Silva et al. (2017). The telomeric probe hybridized to the telomeric regions of both arms of all chromosomes in all 11 species (Fig. 2). However, six species, Marmosops

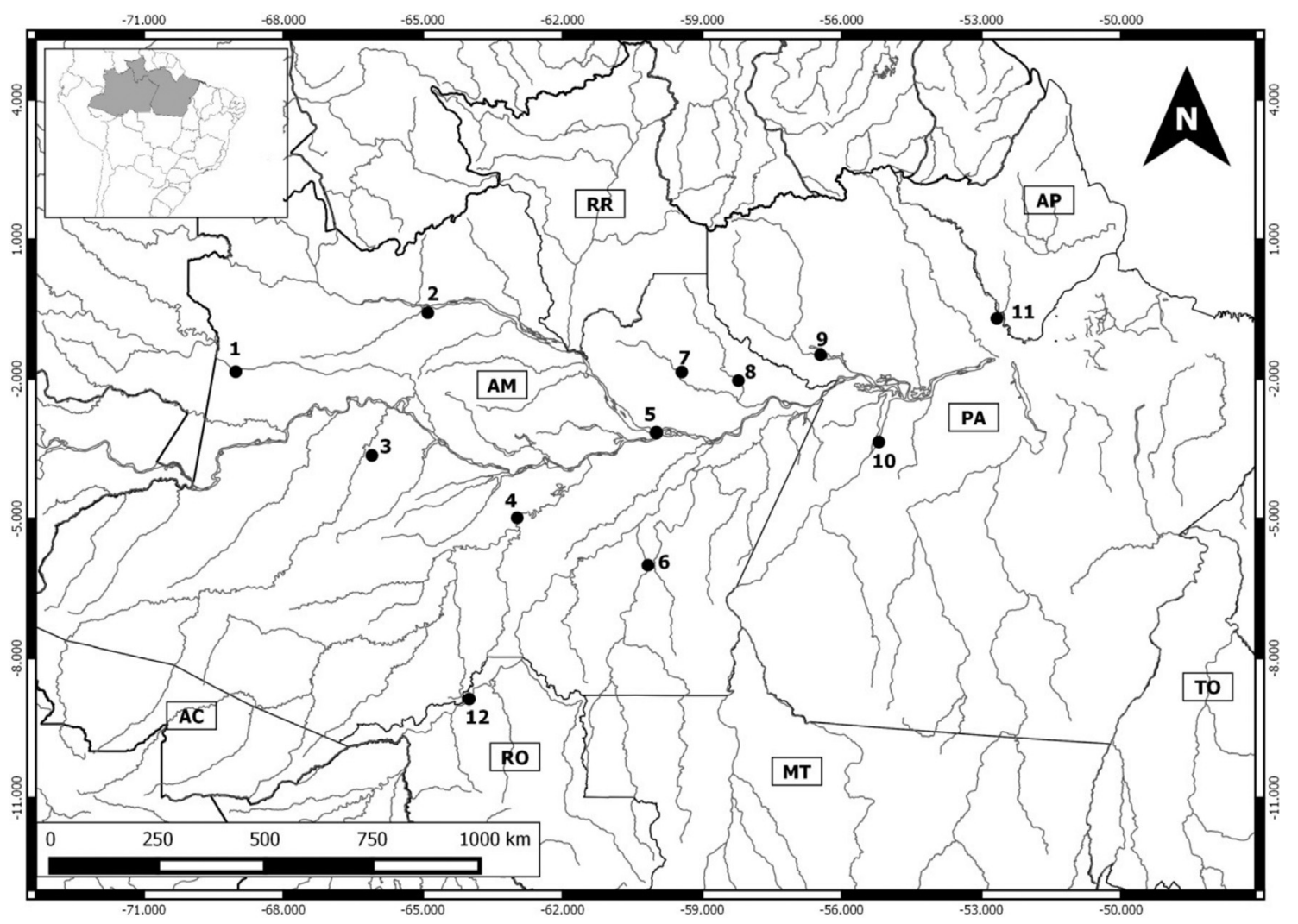

Figure 1 - Collecting sites of marsupials; the locality refers to the municipality and the access river. Collecting localities: Brazilian state of Amazonas (AM): 1- Japurá River margins, municipality of Japurá $\left(1.843416^{\circ} \mathrm{S}, 69.026472^{\circ} \mathrm{W}\right)$; 2 - Negro River margins, Santa Isabel do Rio Negro $\left(0.577250^{\circ} \mathrm{S}\right.$, $\left.64.897694^{\circ} \mathrm{W}\right)$; 3- Juruá River margins, municipality of Juruá $\left(3.641511^{\circ} \mathrm{S}, 66.100691^{\circ} \mathrm{W}\right) ; 4$ - Purus River margins, municipality of Tapauá $\left(4.98066^{\circ} \mathrm{S}\right.$, $\left.62.97700^{\circ} \mathrm{W}\right) ; 5$ - Negro River margins, municipality of Manaus $\left(0.577250^{\circ} \mathrm{S}, 64.897694^{\circ} \mathrm{W} ; 3.133333^{\circ} \mathrm{S}, 59.950000^{\circ} \mathrm{W}\right)$; 6- Aripuanã River margins, municipality of Novo Aripuanã $\left(6.00000000000^{\circ} \mathrm{S}, 60.1666666667^{\circ} \mathrm{W}\right) ; 7$ - Uatumã River margins, municipality of Presidente Figueiredo $\left(1.849988^{\circ} \mathrm{S}\right.$, $\left.59.440200^{\circ} \mathrm{W}\right)$; 8- Jatapu River margins, municipality of São Sebastião do Uatumã (2.017940 $\left.{ }^{\circ} \mathrm{S}, 58.203228^{\circ} \mathrm{W}\right)$; Brazilian state of Pará (PA): 9Trombetas River margins, municipality of Oriximiná $\left(1.481638^{\circ} \mathrm{S}, 56.457333^{\circ} \mathrm{W}\right) ; 10$ - Tapajós River margins, municipalities of Aveiro and Santarém $\left(3.35486111111^{\circ} \mathrm{S}, 55.2031666667^{\circ} \mathrm{W}\right) ; 11$ - Jari River margins, municipality of Monte Dourado $\left(0.700000^{\circ} \mathrm{S}, 52.666666^{\circ} \mathrm{W}\right)$; Brazilian state of Rondônia (RO): 12 - Madeira River margins, municipality of Porto Velho $\left(8.87416^{\circ} \mathrm{S}, 64.007777^{\circ} \mathrm{W}\right)$. DATUM: WGS84. 
Table 1 - Species analyzed in the present study, and the code numbers correspond to the localities on the map (Figure 1).M=number of male individuals; $\mathrm{F}=$ number of female individuals; number of ITS $=$ all counts recorded for the species at the respective locality.

\begin{tabular}{|c|c|c|c|c|}
\hline Species & Locality number in Figure 1 & $\mathrm{M}$ & $\mathrm{F}$ & Number of ITS per individual \\
\hline \multirow[t]{4}{*}{ Caluromys philander } & 10 & 3 & 1 & $0(2)$ \\
\hline & 9 & - & 1 & 0 \\
\hline & 5 & - & 1 & 0 \\
\hline & 4 & - & 1 & 0 \\
\hline Didelphis marsupialis & 5 & 1 & 1 & 0 \\
\hline Glironia venusta & 12 & - & 1 & 0 \\
\hline Gracilinanus cf. peruanus & 10 & 4 & 0 & 0 \\
\hline \multirow[t]{6}{*}{ Marmosa demerarae } & 4 & 1 & 2 & $4,6,7$ \\
\hline & 10 & - & 3 & $6,8,12$ \\
\hline & 9 & 3 & 3 & $6,7,8$ \\
\hline & 11 & 1 & - & 7 \\
\hline & 6 & - & 2 & 12 \\
\hline & 3 & 1 & - & 10 \\
\hline \multirow[t]{4}{*}{ Marmosa murina } & 7 & 1 & 1 & 2 \\
\hline & 4 & 2 & - & 0 \\
\hline & 6 & - & 1 & 0 \\
\hline & 2 & - & 1 & 0 \\
\hline Marmosops cf. pakaraimae & 1 & - & 1 & $12+\mathrm{XX}$ \\
\hline Marmosops parvidens & 9 & 3 & - & $0,2,5,12+X$ \\
\hline \multirow[t]{3}{*}{ Marmosops pinheiroi } & 10 & 1 & - & $12+X$ \\
\hline & 8 & - & 1 & \\
\hline & 9 & 1 & - & \\
\hline Metachirus nudicaudatus & 2 & 2 & 1 & 0 \\
\hline Monodelphis sp. nov. & 4 & 1 & - & 2 \\
\hline
\end{tabular}

pinheiroi (Pine, 1981), Marmosops cf. pakaraimae Voss, Lim, Díaz-Nieto \& Jansa 2013, Marmosops parvidens (Tate, 1931), Marmosa demerarae (O. Thomas, 1905), Marmosa murina (Linnaeus, 1758) and Monodelphis sp., also presented telomeric sequences in the centromeric regions (ITS), which were co-located with the heterochromatin blocks (Figure 2).

Marmosops pinheiroi (Figure 2c) and Marmosops $\mathrm{cf}$. pakaraimae (data not shown) were the species that had the largest number of chromosomes with centromeric ITS, including a conspicuous block in the centromere of the $\mathrm{X}$ chromosome. In Marmosops parvidens (data not shown), variation was found among individuals in the quantity of ITS, with, two, five, and 13 interstitial signals (Table 1). Inter-individual variation was also observed in Marmosa demerarae, which had up to 12 centromeric ITS, on all chromosomes except for the sexual ones (Figure 2d; Table 1). In Marmosa murina, the ITS were located in the centromere of the second autosomal pair and the X chromosome (Fig. 2e). In the case of Caluromys philander Linnaeus, 1758 , a pericentromeric ITS was found in only one individual, collected on the Tapajós River region, in autosomal pair 3 (Figure 2a, box). Monodelphis sp. nov. presented a single ITS in the largest autosomal pair (Figure $2 \mathrm{~h}$ ). No ITS were detected in any of the other species, i.e., Gracilinanus cf. peruanus (O. Thomas, 1909), Metachirus nudicaudatus (Geoffroy-St.Hillaire, 1803), Glironia venusta O. Thomas, 1912 and Didelphis marsupialis Linnaeus, 1758 (Figure 2b, f, g, i). In D. marsupialis, the telomeric sites were much reduced in size in comparison with the other species (Figure $2 \mathrm{i}$ ).

Six principal classes of Interstitial Telomeric Sequence (ITS) are recognized: heterochromatic (het-ITSs), short (s-ITSs), large ITSs in restricted euchromatic regions (Restricted eu-ITSs), long subtelomeric, fusion, and pericentromeric ones (Lin and Yan, 2008; Ruiz-Herrera et al., 2008; Schmid and Steinlein, 2016).

We consider the ITS observed in the present study as being of the het-ITS type, in view of large blocks that coincide with the heterochromatin and vary in number. Metcalfe et al. $(2004,2007)$ recorded a similar scenario in Australian marsupials. If these sequences were in fact related to satellite DNA, rather than rearrangements, a number of questions arise. For example, what may have given rise to the DNA motifs in these regions? Additionally, how can the 


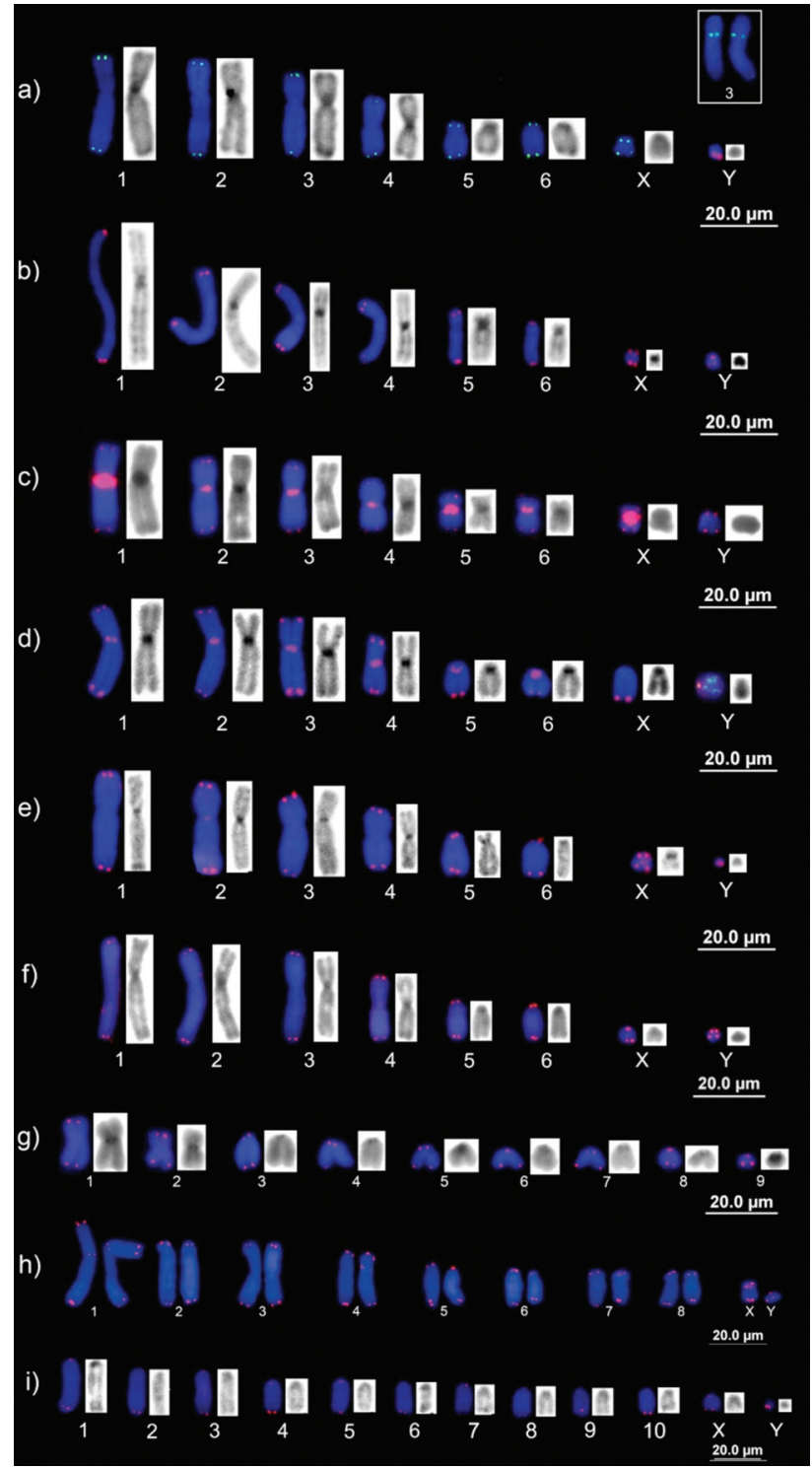

Figure 2 - Chromosomes after the hybridization of the telomeric sequences (left) and after C-banding (right) of: a) Composite karyotype of Caluromys philander (Supplementary Material 1); b) Gracilinanus cf. peruanus; c) Marmosops pinheiroi; d) Marmosa demerarae; e) Marmosa murina; f) Metachirus nudicaudatus; g) Glironia venusta; h) Monodelphis sp. nov.; i) Didelphis marsupialis. The acronyms refer to INPA's collection number and/or field number of the specimens shown in each plate.

inter-individual variation observed in these species be accounted for?

Three principal mechanisms have been proposed to account for the origin of interstitial telomeric sequences: (i) insertions in double-strand breaks, which involve telomerase (Nergadze et al., 2004, 2007), (ii) the fusion of the telomeric regions of chromosomes of different pairs (Bolzán and Bianchi, 2006), and (iii) transposition (Bouffler et al., 1993; Nergadze et al., 2007).

Insertion by repair mechanisms can be a cause. The incidence of solar radiation, in particular ultraviolet radiation has increased progressively and considering that didel- phids fetuses complete their development outside the uterus, it may increase their exposure to radiation and provoke chromosomal breaks (Hartman, 1923; Petrides, 1949; Norval et al., 2007). Telomerase actions could result in the formation of short ITS, subsequently repeated progressively (Messier et al., 1996). Laboratory experiments have demonstrated the occurrence of mutations and chromosomal breaks in Monodelphis domestica (Pathak et al., 1996). However, experiments need to be done to corroborate or refute such a hypothesis. Fusions can be another cause, and recurring points of chromosomal breakage have been identified in marsupials by chromosome painting and G-banding. Chromosomal fusions can be rejected a priori in the family Didelphidae (Pagnozzi et al., 2002; Metcalfe et al., 2004; Westerman et al., 2010). In New World marsupials, chromosomal inversions appear to be more common in the process of chromosomal reorganization (Westerman et al., 2010; Silva et al., 2017). A third possibility is transposition, possibly intermediated by transposable elements (TEs), for example. Retrotransposition has been observed in cell lineages of the Chinese hamster, through retrotransposons of the LINE type (Nergadze et al., 2007).

Irrespective of their origin, it is possible that the het-ITS arose as a short sequence, which was subsequently duplicated, increasing in length, and becoming integrated with the heterochromatin, making it detectable by FISH. This heterochromatinization would provide an alternative mechanism for the reduction of the risk of fissions or other rearrangements, and would account for the association between the ITS and the larger heterochromatin blocks, which are highlighted more intensely by C-banding. Whatever the exact process, it is important to recognize that these ITS arose and were fixed, and thus constitute part of the evolutionary history of the species, even though there is no evidence on their possible adaptive value.

Within the family Didelphidae, these ITS have been fixed, as far as it is known, only in species of the tribes Marmosini (Marmosa spp., Monodelphis spp.) and Thylamyini (Marmosops spp., Gracilinanus microtarsus) (Svartman and Vianna-Morgante, 1998; Carvalho and Mattevi, 2000; Pagnozzi et al., 2002; present study), which did not recover a sister-group relationship (Voss and Jansa, 2009).

In Marmosa murina and C. philander (present study), the variation in the number of ITS was relatively discrete, and in fact, in M. murina, ITS have been observed only in Amazonian individuals, and not in those from other Brazilian regions (Carvalho and Mattevi, 2000; Pagnozzi et al., 2002). In C. philander, the available records were restricted to the Amazonian individuals analyzed by Souza et al. (2013), and now, ITS were also detected in only one individual out of six analyzed in the present study.

Fixation of the ITS and their intraspecific variation appear to be the result of mechanisms that do not involve chromosomal fusion. This indicates that the ITS found in 
Marmosops spp., Marmosa murina, and M. demerarae are the result of the association between these sequences and the heterochromatin, specifically, with certain types of satellite DNA. However, the intraspecific variation found in the number of this marker is not directly related to a phylogenetic pattern, and it will only be possible to better understand the importance of these ITS by discovering the composition of these sequences as a first priority in determining their potential role, and to what extent they are conserved between species.

\section{Acknowledgments}

This study was supported by the Amazonas State Research Support Foundation (FAPEAM), the Brazilian Coordination for Higher Education (CAPES - Brasil, FInance code 001), and the SISBIOTA/BIOPHAM network (CNPq) and Pró-Amazônia (CAPES) projects.

We thank Dr. M.C. Gross and Dr. C.H. Schneider for their cooperation during the development of this research and G.H. Shepard Jr. for reviewing the English of the manuscript. Collecting permits were granted by the Brazilian Institute for the Environment and Renewable Natural Resources (IBAMA), through special licenses 02005.000642/03-11 (IBAMA), 02000.002336/2003-93 (IBAMA), 02005.002672/04 (IBAMA), 37585-5 (SIS$\mathrm{BIO}$ ), and 37592-4 (SISBIO).

\section{Conflict of Interest}

The authors have no conflicts of interest to declare.

\section{Author Contributions}

CEFS, ESE, EF conceived and designed the study; CEFS, ESE collected the samples; CEFS and EMSS performed the cytogenetic analysis; CEFS, ESE, EMSS, MNFS, EF wrote the manuscript and designed the figures; all authors read and approved the final version.

\section{References}

Azzalin CM, Nergadze SG and Giulotto E (2001) Human intrachromosomal telomeric-like repeats: Sequence organization and mechanisms of origin. Chromosoma 110:75-82.

Biggers JD, Fritz WC, Hare WCD and McFeely RA (1965) Chromosomes of American marsupials. Science 148:1602-1603.

Blackburn EH (1991) Structure and function of telomeres. Nature 350:569-573.

Bolzán AD and Bianchi MS (2006) Telomeres, interstitial telomeric repeat sequences, and chromosomal aberrations. Mutat Res 612:189-214.

Bouffler S, Silver A, Papworth D, Coates J and Cox R (1993) Murine radiation myeloid leukaemogenesis: Relationship between interstitial telomere-like sequences and chromosome 2 fragile sites. Genes Chromosomes Cancer 6:98-106.

Carvalho BA and Mattevi M (2000) (T2AG3) n telomeric sequence hybridization suggestive of centric fusion in karyotype marsupials evolution. Genetica 108:205-210.
De Leo AA, Guedelha N, Toder R, Voullaire L,Ferguson-Smith MA, O'Brien PC and Graves JA (1999) Comparative chromosome painting between marsupial orders: Relationships with a $2 \mathrm{n}=14$ ancestral marsupial karyotype. Chromosome Res 7:509-517.

Ford C and Hamerton J (1956) A colchicines hypothonic citrate squash sequence for mammalian chromosomes. Stain Technol 31:247-251.

Hartman CG (1923) The oestros cycles in the opossum. Am J Anat 32:353-395.

Hayman DL and Martin PG (1974) Mammalia I: Monotremata and Marsupialia. In: John B (ed) Animal cytogenetics. Gebrüder Borntraeger, Berlin, pp 1-110.

Hayman DL (1990) Marsupial cytogenetics. Aust J Zool 37:331349.

Ijdo JW, Wells RA, Baldini A and Reeders ST (1991) Improved telomere detection using a telomere repeat probe (TTAGGG)n generated by PCR. Nucleic Acids Res 17:4780.

Lin KW and Yan J (2008) Endings in the middle: Current knowledge of interstitial telomeric sequences. Mutat Res 658:95-110.

McClintock B (1941) The stability of broken ends of chromosomes of Zea mays. Genetics 23:234-282.

Messier W, Li SH and Stewart CB (1996) The birth of microsatellites. Nature 381:483.

Metcalfe CJ, Eldridge MDB and Johnston PG (2004) Mapping the distribution of the telomeric sequence $\left(T_{2} \mathrm{AG}_{3}\right)_{n}$ in the $2 n=14$ ancestral marsupial complement and in the macropodines (Marsupialia: Macropodidae) by fluorescence in situ hybridization. Chromosome Res 12:405-414.

Metcalfe CJ, Eldridge MDB and Johnston PG (2007) Mapping the distribution of the telomeric sequence $\left(\mathrm{T}_{2} \mathrm{AG}_{3}\right)_{\mathrm{n}}$ in the Macropodoidea (Marsupialia) by fluorescence in situ hybridization. II. The ancestral $2 \mathrm{n}=22$ macropodid karyotype. Cytogenet Genome Res 116:212-217.

Meyne J, Ratliff RL and Moyzis RK (1989) Conservation of the human telomere sequence (TTAGGG) ${ }_{\mathrm{n}}$ among vertebrates. Proc Natl Acad Sci 86:7049-7053.

Nagamachi CY, Feldberg E, Pieczarka JC, Pereira AL, Silva CEF, Rosa CC, Souza EMS, Pinto JA, Costa MJR, Malcher SM et al. (2015) Citogenética de pequenos mamíferos não-voadores da Amazônia brasileira. In: Mendes-Oliveira AC and Miranda C (eds) Pequenos Mamíferos não-voadores da Amazônia Brasileira. 1st ed. Sociedade Brasileira de Mastozoologia, Rio de Janeiro, pp 275-307.

Nergadze SG, Rocchi M, Azzalin CM, Mondello C and Giulotto E (2004) Insertion of telomeric repeats at intrachromosomal break sites during primate evolution. Genome Res 14:1704-1710.

Nergadze SG, Santagostino MA, Salzano A, Mondello C and Giulotto E (2007) Contribution of telomerase RNA retrotranscription to DNA double-strand break repair during mammalian genome evolution. Genome Biol 8:260.

Norval M, Cuellen AP, Gruijl FR, Longstreth J, Takizawa Y, Lucas RM, Noonang FP and van der Leun JC (2007) The effects on human health from stratospheric ozone depletion and his interaction with climate change. Photochem Photobiol Sci 6:232-251.

O'Neill RJW, Eldridge MDB, Toder R, Ferguson-Smith MA,O'Brien PC andGraves JA (1999) Chromosome evolution in kangaroos (Marsupialia: Macropodidae): Cross species chromosome painting between the tammar wallaby and 
rock wallaby spp. with the $2 \mathrm{n}=22$ ancestral macropodid karyotype. Genome 42:525-530.

Pagnozzi JM, Silva MJJ and Yonenaga-Yassuda Y (2000) Intraspecific variation in the distribution of the interstitial telomeric (TTAGGG) $)_{n}$ sequences in Micoureus demerarae (Marsupialia: Didelphidae). Chromosome Res 8:585-591.

Pagnozzi JM, Ditchfield AD and Yonenaga-Yassuda Y (2002) Mapping the distribution of the interstitial telomérica (TTAGGG $)_{\mathrm{n}}$ sequences in eight species of Brazilian marsupials (Didelphidae) by FISH and the correlation with constitutive heterochromatin. Do ITS represent evidence for fusion events in American marsupials? Cytogenet Genome Res 98:278-284.

Pathak S, Multani AS and Amass JMS (1996) Telomere, telomerase a malignant melanomas in human and domestic mammals. Arch Zootec 45:141-149.

Patton JL (1967) Chromosome studies of certain pocket mice, genus Perognathus (Rodentia: Heteromyidae). J Mammal 48:27-37.

Petrides GA (1949) Sex and age determination in the opossum. J Mammal 30:364-378.

Pinkel D, Straume T and Gray JW (1986) Cytogenetic analysis using quantitative, high sensitivity, fluorescence hybridization. Proc Natl Acad Sci U S A 83:2934-2938.

Reig OA, Gardner AL, Bianchi NO and Patton JL (1977) The chromosomes of Didelphidae (Marsupialia) and their evolutionary significance. Biol J Linn Soc 9:191-216.

Rens W, O'Brien PCM, Yang F, Graves JAM and FergusonSmith MA (1999) Karyotype relationships between four distantly related marsupials revealed by reciprocal chromosome painting. Chromosome Res 7:461-474.

Rens W, O'Brien PCM, Fairclough H, Harman L, Graves JA andFerguson-Smith MA (2003) Reversal and convergence in marsupial chromosome evolution. Cytogenet Genome Res 102:282-290.

Rofe R and Hayman D (1985) G-banding evidence for a conserved complement in the Marsupialia. Cytogenet Genome Res 39:40-50.

Ruiz-Herrera A, Nergadze SG, Santagostino M and Giulotto E (2008) Telomeric repeats far from the ends: Mechanisms of origin and role in evolution. Cytogenet Genome Res 122:219-228.

Sánchez J, Bianchi MS and Bolzán AD (2010) Relationship between heterochromatic interstitial telomeric sequences and chromosome damage induced by the radiomimetic com- pound streptonigrin in Chinese hamster ovary cells. Mutat Res 684:90-97.

Schmid M and Steinlein C (2016) Chromosome banding in Amphibia. XXXIV. Intrachromosomal telomeric DNA sequences in Anura. Cytogenet Genome Res 148:211-226.

Sharman GB (1961) The mitotic chromosomes of marsupials and their bearing on taxonomy and phylogeny. Aust J Zool 9:38-60.

Sharman GB (1982) Karyotypic similarities between Dromiciops australis (Microbiotheriidae, Marsupialia) and some Australian marsupials. In: Archer M (ed) Carnivorous marsupials Volume 1. Royal Zoological Society of NSW and Surrey Beatty and Sons, Sydney, Australia, pp 711-714.

Silva CEF, Andrade RA, Souza EMS, Eler ES, da Silva MNF and Feldberg E (2017) Comparative cytogenetics of some marsupial species (Didelphimorphia; Didelphidae Gray, 1821) from the Amazon basin. Comp Cytogenet 11:703-725.

Souza EMS, Silva CEF, Eler ES, da Silva MNF and Feldberg E (2013) Variations of chromosomal structures in Caluromys philander (Didelphimorphia: Didelphidae) from the Amazon region. Genetica 141:89-93.

Sumner AT (1972) A simple technique for demonstrating centromeric heterochromatin. Exp Cell Res 75:304-306.

Svartman M and Vianna-Morgante AM (1998) Karyotype evolution of marsupials: From higher to lower diploid numbers. Cytogenet Cell Genet 82:263-266.

Svartman M (2009) American marsupial chromosomes: Why study them? Genet Mol Biol 32:675-687.

Voss R and Jansa S (2009) Phylogenetic relationships and classification of didelphid marsupials, an extant radiation of new world metatherian mammals. Bull Am Mus Nat Hist 322:1177.

Westerman M, Meredith RW and Springer MS (2010) Cytogenetics meets phylogenetics: A review of karyotype evolution in diprotodontian marsupials. J Hered 101:690-702.

\section{Supplementary material}

The following online material is available for this article Supplementary Material 1

Associate Editor: Yatiyo Yonenaga-Yassuda

License information: This is an open-access article distributed under the terms of the Creative Commons Attribution License (type CC-BY), which permits unrestricted use, distribution and reproduction in any medium, provided the original article is properly cited. 